\title{
Use of Instagram, Social Comparison, and Personality as Predictors of Self-Esteem
}

\author{
Luiza Seabra Fagundes ${ }^{1}$ \\ Tiago Azevedo Marot ${ }^{1}$ \\ Jean Carlos Natividade ${ }^{1}$ \\ ${ }^{1}$ Pontifícia Universidade Católica do Rio de Janeiro, Rio de Janeiro, Rio de Janeiro, Brasil
}

\begin{abstract}
In the face of a population that is increasingly connected electronically, the objective of this research was to test the predictive power of Instagram's use intensity, social comparison and the five major personality factors of self-esteem. The survey, made available on the internet with sociodemographic questions and four scales, was answered by 625 Brazilians, of which $63.7 \%$ were women. The results indicated neuroticism and social comparison (abilities factor) as negative predictors of self-esteem. Extraversion, agreeableness, consciousness, social comparison (opinions factor), and age were shown to be positive predictors of self-esteem. For women, the higher the intensity of Instagram's use, the lower the levels of self-esteem. The negative relationship between self-esteem and the intensity of Instagram use was mediated by social comparison (suppression effect). It is suggested that the harm of using the social network relates to the activity of comparing himself to other people. Keywords: Instagram; self-esteem; social comparison; personality traits.
\end{abstract}

Uso do Instagram, Comparação Social e Personalidade como Preditores da Autoestima

\begin{abstract}
Resumo
Diante de uma população cada vez mais conectada virtualmente, o objetivo desta pesquisa foi testar o poder preditivo da intensidade de uso do Instagram, da comparação social e dos cinco grandes fatores de personalidade sobre a autoestima. O questionário, disponibilizado na internet com perguntas sociodemográficas e quatro escalas, foi respondido por 625 brasileiros, sendo 63,7 $\%$ mulheres. Os resultados indicaram o neuroticismo e a comparação social (fator habilidades) como preditores negativos da autoestima. A extroversão, a socialização, a realização, a comparação social (fator Opiniões) e a idade mostraram-se preditores positivos da autoestima. Para as mulheres, quanto maior a intensidade de uso do Instagram, menores os níveis de autoestima. A relação negativa entre a autoestima e a intensidade de uso do Instagram foi mediada pela comparação social (efeito de supressão). Sugere-se que os prejuízos do uso da rede social para o indivíduo relacionam-se com a atividade de comparar-se com outras pessoas.

Palavras-chave: Instagram, autoestima, comparação social, traços de personalidade.
\end{abstract}

Uso de Instagram, Comparación Social y Personalidad como Predictores de la Autoestima

\begin{abstract}
Resumen
Ante una población cada vez más conectada virtualmente, el objetivo de esta investigación fue probar el poder predictivo de la intensidad de uso de Instagram, de la comparación social y de los cinco grandes factores de personalidad sobre la autoestima. El cuestionario, disponible en Internet con preguntas sociodemográficas y cuatro escalas, fue respondido por 625 brasileños, siendo $63,7 \%$ mujeres. Los resultados indicaron el neuroticismo y la comparación social (factor habilidades) como predictores negativos de la autoestima. La extroversión, la socialización, la realización, la comparación social (factor opiniones) y la edad se mostraron predictores positivos de la autoestima. Para las mujeres, cuanto mayor es la intensidad de uso de Instagram, más bajos los niveles de autoestima. Se medió la relación negativa entre autoestima e intensidad de uso de Instagram por comparación social (factor habilidad). Se sugieren los perjuicios del uso de la red social para el individuo se relacionan con la actividad de compararse con otras personas.

Palabras clave: Instagram; autoestima; comparación social; rasgos de personalidad.
\end{abstract}

Over the past few years, the use of online social networks for social and entertainment activities has become popular around the world (Andreassen, Pallesen, \& Griffiths, 2017; Kuss \& Griffiths, 2011). Global statistics show that, by the beginning of 2019, 3.5 billion people $-58 \%$ of the world's population over 13 years old - were using online social networks. The number of users doubled from 2014 to 2019, revealing the increasing demand for virtual contact. The time spent on social media per day also grew gradually. In Brazil, users spend, on average, three hours and 34 minutes a day on online social networks, leading the ranking together with Filipino users, who spend four hours and 12 minutes daily on them (Kemp, 2019).

More specifically, Instagram stands out in the world scene in regard to the number of users. In June 2018, Instagram had 1 billion active users per month, $64 \%$ of whom were young adults between the ages of 
18 and 34. Despite the uniform adherence of men and women to this social network, $49.7 \%$ and $50.3 \%$ respectively, in terms of frequency and intensity, women use it more (Clement, 2019a). Brazil assumes an important position in the global panorama with 72 million registered users, behind only the United States and India, which have 116 million and 73 million users, respectively (Clement, 2019b).

This growth at an exponential pace suggests that online social networks play a relevant role in the way individuals interact and present themselves to one another nowadays (Kross et al., 2013). This form of interaction and presentation to the world can impact on the formation of self-concept or even the capability of individuals to assess their self-concepts (their selfesteem). Recent studies point to the effects, positive and negative, of the use of Instagram on self-assessment and, also, on interpersonal relationships, which are an important pillar of self-esteem (e.g., Stapleton, Luiz, \& Chatwin, 2017; Trifiro, 2018). On the one hand, online social networks satisfy, in part, the need for social attachment by providing the feeling of belonging to the environment. However, on the other hand, the virtual environment can be a source of suffering by providing the conditions for comparison with other users and by influencing the way the individual perceives himself/ herself (Verduyn, Ybarra, Résibois, Jonides, \& Kross, 2017). In the face of a population that is more and more virtually connected, it is necessary to understand how the intensity of Instagram use, social comparison and personality predict the self-esteem of people who use this online social network.

Online social networks generally differ both in terms of their purpose of use and in terms of the predominant form of communication. A distinguishing feature of Instagram in relation to other online social networks is its exclusive focus on the publication of photos or videos, which can be accompanied by short texts - the captions. The possibility of applying different "filters" allows the users to change the colors of their images, which sometimes become far from reality (Vries, Möller, Wieringa, Eigenraam, \& Hamelink, 2017).

In general, publications exposed to other participants in the online social network are positively biased due to the tendency of users to select and emphasize desirable aspects of themselves or of their lives (Reinecke \& Trepte, 2014). The opportunity to improve photos or videos by manipulating their aesthetic characteristics, stimulates the creation of a culture of perfection, which can be associated, by some individuals, with a feeling of frustration due to the attempt to reach unrealistic and sometimes unattainable standards published by other users (Lup, Trub, \& Rosenthal, 2015). In addition, another peculiarity of Instagram is the non-reciprocal connection between users, one person may "follow" another person that does not follow him/her in return (Hu, Manikonda, \& Kambhampati, 2014). The specifics of Instagram, as an online social network with essentially imagery content, can impact on the perception of self, self-concept and self-esteem of its users, especially if they adopt a comparative perspective in regard to themselves.

\section{Self-esteem and online social networks}

Self-concept refers to the sum of the individual's beliefs about himself/herself, that is, his/her global self-perception (Heatherton \& Wyland, 2003). Selfesteem, in turn, consists of the attitude - positive or negative - towards self-concept (Rosenberg, Schooler, Schoenbach, \& Rosenberg, 1995). Thus, self-esteem is the individual's assessment of himself/herself. Generally speaking, this assessment tends to remain stable throughout life (see Chung et al., 2014; Trzesniewski, Donnellan, \& Robins, 2003). However, some everyday situations can impact on self-esteem and cause behavioral changes. For example, a person can publish a photo, receive few likes, evaluate himself/herself negatively - as not deserving the approval of others - and, consequently, keep out of social interactions due to insecurity.

Although it is not possible to say that the use of Instagram causes changes in the levels of self-esteem, different researches have shown correlations between self-esteem and the use of online social networks (e.g., Andreassen et al., 2017; Jan, Soomro, \& Ahmad, 2017; Lee, 2014; Malik \& Khan, 2015; Schmuck, Karsay, Matthes, \& Stevic, 2019; Vogel, Rose, Roberts, \& Eckles, 2014). In a recent study, for example, Schmuck et al. found, in Germany, a negative correlation between the use of Instagram and levels of self-esteem. Despite the impossibility of inferring a causal relationship between the variables, one may suggest that people use online social networks as a way to test their social approval, for instance, through likes. Another possibility is that online social networks will serve as a way to avoid the feelings arising from low self-esteem, with people seeking, for example, a feeling of belonging to the social environment. Social relationships and feedback from people considered important play an important role in 
the individual's assessment of himself/herself (Leary, Tambor, Terdal, \& Downs, 1995).

In Pakistan, Jan et al. (2017) found that the time spent on Facebook negatively predicts self-esteem. In the United States, Lee (2014) found that the longer the time spent on the social network, the lower the levels of self-esteem and the greater the losses for the individual (such as less self-confidence and a greater feeling of inadequacy and incompetence). On the other hand, in Taiwan, Hong, Huang, Lin and Chiu (2014) found no relationship between the use of Facebook, the time spent on the network, and self-esteem. Similarly, in Australia, Stapleton et al. (2017) did not observe a direct relationship between the intensity of Instagram use and self-esteem. However, they revealed that the intensity of Instagram use is able to predict social comparison, which, in turn, predicts self-esteem.

The results of Stapleton et al. (2017) showed that the greater the intensity of Instagram use, the higher the levels of comparison with other users. In addition, the higher the levels of social comparison, the lower the levels of self-esteem. When participating in online social networks, the individual not only exposes his/her life to the observation of others, but is also exposed to that of others, which enables him/her to carry out selfassessment based on what he/she sees virtually. Wang, Wang, Gaskin and Hawk (2017), for example, found that the use of online social networks is positively associated with upward social comparison, which, in turn, is negatively related to self-esteem. Thus, upward social comparison is shown to mediate the relationship between the use of online social networks and selfesteem (Vogel et al., 2014; Wang et al., 2017).

The use of online social networks, such as Instagram, offers rich opportunities for users to evaluate themselves based on what they observe about third parties in a virtual environment, and this reverberates, for example, in self-esteem (e.g., Vogel et al., 2014; Yang, 2016). Social comparison consists of comparing oneself with others for the purpose of evaluating oneself - in relation to abilities and opinions, for example - or improving certain aspects of oneself (Festinger, 1954). Thus, when the individual engages in a social comparison, he/she judges whether he/she is better or worse than the target of his/her comparison (Festinger, 1954). In addition to the evaluative function, social comparison also contemplates the aspect of self-knowledge. When comparing himself/herself with others, the individual learns to know himself/herself (Festinger, 1954; Gibbons \& Buunk, 1999; Wood, 1989).
Considering that self-perception influences the way the individual shows up on Instagram, it is important to highlight the opportunity offered to users to present themselves in an unrestricted way and to handle the impression they want to cause (Walther, 2007; Wang et al., 2017). The handling of this impression online allows the individual to adjust his image to his/her goals and needs for social interaction. However, there is a tendency to engage in favorable self-presentation, that is, socially desirable, which makes the users shy away from their reality to show themselves in an idealized way, emphasizing attractive traits (Ellison, Heino, \& Gibbs, 2006 ; Lee, 2014; Lee-Won, Shim, Joo, \& Park, 2014; Lin \& Utz, 2015; Vogel et al., 2014; Wang et al., 2017). Instagram users, for example, can transmit their personal characteristics through image publications, sometimes intentionally modified, which can be used for comparison by other users of the online social network who access their profile.

Some studies have already been carried out with the aim of understanding the relationship between the use of online social networks, social comparison and self-esteem (e.g., Stapleton et al., 2017; Vogel et al., 2014). The results have shown that the greater the frequency of using Facebook, the higher the levels of social comparison, especially upward social comparison (Lee, 2014; Vogel et al., 2014). Furthermore, the relationship between the frequency of using Facebook and self-esteem was significantly mediated by upward social comparison (Vogel et al., 2014). Similar results were also found for Instagram (e.g., Stapleton et al., 2017).

Even though social comparison on Instagram is negatively associated with self-esteem, it correlates positively with the level of inspiration of users, defined as a motivational state that can be experienced in different areas of life (Meier \& Schäfer, 2018). From this perspective, the greater the social comparison, the lower the self-esteem and the greater the level of inspiration, which suggests that the network participants observe others and feel motivated for self-improvement. Thus, social comparison can be associated with benefits or harms to the individual who practices it.

\section{Self-esteem, personality and online social networks}

An important construct that must be taken into account in the relationship between the use of online social networks, social comparison and self-esteem is personality. In national and international research, personality has proved to be related to self-esteem (e.g., Frost \& Natividade, 2017; Hong et al., 2014; 
Hutz, Zanon, \& Vazquez, 2014; Natividade \& Hutz, 2016; Robins, Tracy, Trzesniewski, Potter, \& Gosling, 2001). Although it is not possible to infer causality in the relationship between self-esteem and the five major personality factors, different studies have shown positive correlations, ranging from strong to moderate ones, between self-esteem and the factors of emotional stability - the opposite of neuroticism - and extraversion (e.g., Frost \& Natividade, 2017; Hong et al., 2014; Kwan, Bond, \& Singelis, 1997; Pullman \& Allik, 2000; Robins, Hendin, \& Trzesniewski, 2001; Robins et al., 2001).

Personality traits are important in understanding the complexities of human behavior in different situations, including academic success (e.g., Komarraju, Karau, \& Schmeck, 2009), job performance (e.g., Neal, Yeo, Koy, \& Xiao, 2012), success in love relationships (e.g., Donnellan, Larsen-Rife, \& Conger, 2005), alcohol use (e.g., Natividade, Aguirre, Bizarro, \& Hutz, 2012), self-esteem (e.g., Natividade \& Hutz, 2016), subjective well-being (e.g., Natividade et al., 2019; Woyciekoski, Natividade, \& Hutz, 2014) and online behavior (e.g., Kayis et al., 2016; Ko et al., 2006; Wang, 2013). In this sense, the individual characteristics of users can impact on their use of online social networks. These psychological aspects of individuals can inform both their motivations to be part of online social networks and their different forms of use (Kircaburun \& Griffiths, 2018).

Zúñiga, Diehl, Huber and Liu (2017) conducted a comprehensive survey in 20 countries, including Brazil, with the aim of understanding the relationship between the use of online social networks and the big five personality factors. The results highlighted the factors of extraversion, agreeableness, conscientiousness and openness to experiences as positive predictors of the frequency of use of online social networks. The emotional stability factor - the opposite of neuroticism - was the only negative predictor of this frequency of use. In view of these results, it is possible to assume that individuals with high levels of extraversion and agreeableness, that is, those who tend to feel comfortable in social interactions, find in online social networks an opportunity to satisfy their needs for contact and proximity with others. Moreover, individuals with high levels of openness to experiences can use these social networks as an alternative to explore novelties and satisfy their curiosity.

Although research on the use of online social networks is steadily advancing, it is important to consider that each one of them has specificities that make it different from the others. Regarding Instagram, there are still few scientific studies that explain which variables are capable of predicting users' behavior (Kircaburun \& Griffiths, 2018). The current literature comprises research that separately links self-esteem with the use of different online social networks, social comparison and personality. Based on the need to understand these variables together, the present study aimed to test the predictive power of the intensity of Instagram use, social comparison and the big five personality factors on self-esteem. In addition, this study had a secondary goal of verifying the differences between men and women in the accessed variables.

\section{Method}

\section{Participants}

The participants were 625 Brazilians from the five regions of the country, with an average age of 26.7 years $(S D=8.18)$, and $63.7 \%$ of them $(n=398)$ were women. Everyone claimed to be an Instagram user. As for education, $53.3 \%(n=333)$ had incomplete undergraduate; the rest $(46.7 \% ; n=292)$ had complete undergraduate, $12.3 \%(n=36)$ of whom had incomplete graduate level and $46.6 \%(n=136)$ complete graduate level. Most respondents lived in the Southeast region of Brazil, $84.8 \%(n=530)$; the Midwest region had 5.5\% $(n=35)$ of the participants; the South region had 5.3\% $(n=33)$; the Northeast region had 3.9\% $(n=24)$; and, finally, the North region had $0.3 \%(n=2)$; the remaining $0.2 \%(n$ $=1$ ) declared to be abroad at the time of the survey. The average number of Instagram accesses per day was nine times $(S D=10.3)$ with an average of 1 hour spent daily on Instagram $(S D=1.15)$.

\section{Instruments}

An online questionnaire was used, available at an internet address. The questionnaire contained sociodemographic questions (gender, age, education, profession, place of residence, among others) and questions about the use of Instagram (approximate number of profiles followed, approximate number of followers, number of accesses per day, time spent on the network per day, types of photos most published, content of the last publication, number of likes from the last publication). In addition to these questions, the questionnaire contained scales to assess self-esteem, the intensity of Instagram use, social comparison, and personality. Besides the items on the scales, control items 
were included, in which the participant was asked to respond in a specific way (e.g., please mark number five as an answer) in order to ensure that everybody was reading the items. The questionnaire was configured so as to prevent missing answers to the scale items.

Rosenberg's Self-Esteem Scale (Rosenberg, 1965; adapted for Brazil by Hutz \& Zanon, 2011). It is a onedimensional instrument consisting of 10 statements to assess global self-esteem, with five items referring to a positive view of oneself and five referring to a selfdeprecating view. Items are answered on a four-point scale, ranging from 1 - strongly disagree to 4 - strongly agree. Examples of items: "I think I have several good qualities"; "Sometimes I feel useless". The closer the participant's average is to four, the greater the selfesteem. In the study by Hutz and Zanon, the scale showed internal consistency, Cronbach's alpha, of .90 .

Intensity of Instagram Use Scale - IIUS (developed in this study, and inspired by Ellison, Steinfield, \& Lampe, 2007). It is a one factor scale composed of ten items, two inverted, to assess the intensity of Instagram use. The intensity of Instagram use construct refers to the users' subjective perception of the extent to which Instagram is part of their daily activities, especially in terms of time consumption. The intensity of use also includes the degree of emotional involvement of the participant with Instagram. The instrument's items are answered on a five-point scale, which ranges from 1 - totally disagree to 5 - totally agree. Examples of items: "I usually use Instagram whenever I have free time"; "I lose track of time when I'm using Instagram"; "Sometimes I even forget that I have Instagram"; "I feel an overwhelming need to use Instagram." The closer the participant's average is to five, the greater the intensity of use. The instrument had adequate internal consistency with an alpha coefficient of .85 and an omega of .88. The Intensity of Instagram Use Scale correlated with the question "If you could assess your level of intensity of Instagram use, how would it be? $(0=$ not at all intense; $100=$ extremely intense)", $r(625)=.76, p<.001$.

Iowa-Netherlands Comparison Orientation Measure - INCOM (Gibbons \& Buunk, 1999; Brazilian version of Bastos, Marot, \& Natividade, 2019; similar to the Portuguese version of Lins et al., 2016). It is an instrument composed of 11 items that measure individual differences in the tendency to make social comparison within the scope of two dimensions: abilities (six items) and opinions (five items). The abilities factor refers to the comparison of capacities
/ aptitudes. The opinions factor concerns the comparison of feelings and thoughts. The statements are answered on a five-point scale, so that 1 - strongly disagree and 5 - strongly agree. Examples of items: "I often compare myself with others with respect to what I have accomplished in life"; "If I want to learn more about something, I try to find out what others think about it." The closer the participant's average is to seven, the higher the level of social comparison. In the study by Gibbons and Buunk, the alpha coefficients ranged from .77 to .85 , whereas in the study by Bastos et al. the alpha coefficient for abilities was .79 and for opinions was .67.

Reduced Scale of Personality Descriptors - RED5 (Natividade \& Hutz, 2015). This instrument consists of 20 items that assess personality characteristics from the perspective of the big five factors: extraversion, agreeableness, conscientiousness, neuroticism and openness to experiences. The items, four per factor, are adjectives or small expressions, such as "communicative", "emotionally stable", "being curious". The participant must answer on a seven-point scale the extent to which he/ she agrees that each adjective or expression adequately describes him/her, so that 1 - strongly disagree and 7 - strongly agree. The closer the averages for the factors are to seven, the greater the intensity of the traits. Natividade and Hutz found alpha coefficients between .59 to .84 on the factors, and test-retest correlations from .69 to .81 .

\section{Procedures}

For data collection. Data collection was performed through an online questionnaire available on online social networks and on the laboratory's website. In addition to internet recruitment, the procedure for recruiting participants combined face-to-face contact on the premises of (this information was removed by the magazine) with virtual connection - Online Collection with Face-to-face Recruitment (see Wachelke, Natividade, Andrade, Wolter, \& Camargo, 2014). The members of the laboratory informed the candidates to participants about the purpose of the research and what their participation would consist of. Those who agreed to participate provided their email addresses. Invitation e-mails with the questionnaire's e-mail address were sent to those that agreed to participate. In addition, data collection was carried out in person on the laboratory's data collection computers. Participants were personally recruited and taken to the laboratory to answer the questionnaire. The present research respected the 
ethical guidelines in force in Brazil for research with human beings, it was approved by the ethics committee under protocol number: 2.690.491.

For analyses. Initially, the database was cleaned up, excluding participants who provided wrong answers to the control items. Then, the averages of the participants on the scales, the standard deviations and the internal consistency coefficients, Cronbach's alpha, were calculated. Afterwards, the mean differences between men and women were tested for the constructs examined in the study, using Student's t-tests. Next, Pearson's correlation analyzes were performed to verify the relationship between the variables, separately for men and women.

In order to test the predictive power of demographic variables (gender and age), personality, social comparison and the intensity of Instagram use on self-esteem, a hierarchical regression analysis, Enter method, was performed. The first block contained the sex variable, where $0=$ woman and $1=$ man, the age and the big five personality factors. In the second block, the two factors of social comparison were included. In the third, the intensity of Instagram use. We chose this sequence of blocks for the predictors according to the theoretical logic of starting with more individual variables and moving on to more contextual ones.

Finally, in view of the results of other studies (e.g., Stapleton et al., 2017; Vogel et al. 2014; Wang et al., 2017), mediation analyzes were carried out to understand the effects of the abilities and opinions factors of social comparison on the relationship between the intensity of Instagram use and self-esteem. To this purpose, we used the software $\mathrm{R}$, version 3.6.1 (R Core Team, 2019) and the lavaan package, version 0.6-5 (Rosseel, 2012). Two models were configured, one for the abilities factor and the other for the opinions factor, and the direct effect of the intensity of Instagram use on self-esteem and its indirect effect via social comparison were tested (see Hayes, 2018). For both models, the Maximum Likelihood estimator was used, bootstrap method with 1000 simulated samples.

\section{Results}

Initially, the means and standard deviations for the constructs accessed in this study were calculated. The results can be seen in Table 1 . Then, differences in the means between men and women were tested. Differences were found in the levels of intensity of Instagram use, $t(538.3)=5.45, p<.001, d=0.42$, neuroticism, $t(623)=5.54, p<.001, d=0.46$, and conscientiousness, $t(623)=4.25, p<.001, d=0.35$, with women presenting higher averages. There were no differences in means between men and women in the levels of self-esteem, $t(623)=-1.41, p=.16, d=0.12$, social comparison abilities factors, $t(623)=1.17, p=.24, d=0.10$, and opinions factors, $t(623)=0.40, p=.69, d=0.03$, extraversion, $t(623)=0.94, p=.35, d=0.08$, agreeableness, $t(530.3)=-0.80, p=.43, d=0.06$, and openness to experiences, $t(623)=5.45, p=.34, d=0.08$.

Table 1 also shows Pearson's correlation coefficients between the variables of this study. There were significant negative correlations between self-esteem and social comparison in its two dimensions, abilities and opinions, both for men and women, being stronger for women. Self-esteem showed a significant negative correlation with the intensity of Instagram use for women. Both for men and women, the intensity of Instagram use showed a significant positive correlation with social comparison in its abilities and opinions dimensions, and also with neuroticism.

In the predictive model, Table 2, the individual variables (sex, age and the big five personality factors) explained $47 \%$ of the variance in self-esteem; social comparison explained another $4 \%$ of the variance; and the intensity of Instagram use added no explanation for the variance. Age, the extraversion, agreeableness and conscientiousness factors of personality and the opinions factor of social comparison were positive predictors of self-esteem; whereas the neuroticism factor of personality and the abilities factor of social comparison were negative predictors. The neuroticism factor of personality and the abilities factor of social comparison stand out as the predictors with the highest standardized regression coefficients (betas).

Considering that the correlation between the intensity of Instagram use and self-esteem was weak, and taking into account the results of previous studies on the mediating role of social comparison (e.g., Stapleton et al., 2017; Vogel et al., 2014; Wang et al., 2017), mediation models were tested, including the abilities and opinions factors of social comparison as a mediator (i.e., suppressor) of the relationship between intensity of use and self-esteem. The tested models showed that the direct relationship between the intensity of Instagram use and self-esteem is not significant; however, when the factors of social comparison are added, the (negative) relationship between the intensity of Instagram use and self-esteem becomes significant (suppression effect). Figures 1 and 2 show 
Table 1.

Correlations among Self-esteem, Intensity of Instagram Use, Social Comparison, Personality, for Men and Women

\begin{tabular}{lllllllllllll}
\hline & 1 & 2 & 3 & 4 & 5 & 6 & 7 & 8 & 9 & 10 & $M$ & $S D$ \\
\hline 1. Self-Esteem & $. .91)$ & $-.15^{* *}$ & $-.52^{* *}$ & $-.31^{* *}$ & $.34^{* *}$ & $.37 * *$ & $-.53^{* *}$ & $.39^{* *}$ & $.14^{* *}$ & $.37 * *$ & 2.97 & 0.65 \\
2. Int. Insta Use & -.12 & $. .85)$ & $.22^{* *}$ & $.32^{* *}$ & .10 & -.02 & $.14^{* *}$ & $-.14^{* *}$ & .01 & $-.30^{* *}$ & 2.87 & 0.86 \\
3. SC Abilities & $-.29^{* *}$ & $.22^{* *}$ & $(.81)$ & $.59^{* *}$ & $-.17^{* *}$ & $-.13^{*}$ & $.43^{* *}$ & $-.22^{* *}$ & $-.15^{* *}$ & $-.32^{* *}$ & 3.13 & 0.87 \\
4. SC Opinions & $-.14^{*}$ & $.24^{* *}$ & $.62^{* *}$ & $(.70)$ & -.02 & .03 & $.37^{* *}$ & $-.24^{* *}$ & $-.10^{*}$ & $-.34^{* *}$ & 3.53 & 0.73 \\
5. Extraversion & $.43^{* *}$ & .03 & -.06 & .10 & $(.87)$ & $.46^{* *}$ & -.05 & .02 & $.28^{* *}$ & $.16^{* *}$ & 4.55 & 1.58 \\
6. Agreeableness & $.36^{* *}$ & .06 & -.01 & $.16^{*}$ & $.51^{* *}$ & $(.83)$ & $-.27^{* *}$ & $.25^{* *}$ & .10 & $.11^{*}$ & 5.78 & 1.12 \\
7. Neuroticism & $-.46^{* *}$ & $.17^{*}$ & $.28^{* *}$ & $.25^{* *}$ & -.08 & $-.19^{* *}$ & $(.68)$ & $-.28^{* *}$ & -.05 & $-.24^{* *}$ & 4.20 & 1.23 \\
8. Consciousness & $.36^{* *}$ & -.01 & -.10 & -.11 & .12 & $.17 * *$ & $-.19^{* *}$ & $(.74)$ & -.04 & $.14^{* *}$ & 5.17 & 1.22 \\
9. Openness & $.23^{* *}$ & -.08 & -.07 & .03 & $.32^{* *}$ & $.27 * *$ & -.04 & .04 & $.58)$ & .03 & 5.08 & 0.99 \\
10. Age & $.34^{* *}$ & -.12 & -.11 & -.12 & $.17 *$ & .07 & $-.13^{*}$ & $.17 *$ & .03 & - & 27.2 & 8.74 \\
M & 3.05 & 2.52 & 3.05 & 3.50 & 4.43 & 5.85 & 3.64 & 4.74 & 5.16 & 25.8 & & \\
SD & 0.64 & 0.73 & 0.82 & 0.66 & 1.52 & 0.96 & 1.21 & 1.18 & 1.03 & 7.04 & &
\end{tabular}

Note. Int. Insta Use = Intensity of Instagram Use; SC Abilities = Social Comparison - ability fator; SC Opinions = Social Comparison - opinion factor. Above the main diagonal, women results, $N=398$; below the main diagonal, men results, $N=227$. Alpha coefficients are in the main diagonal within parenthesis.

${ }^{*} p<.05$

** $p<.01$

Table 2.

Predictor Variables of Self-Esteem Utilizing Hierarchical Linear Regression, Enter Method

\begin{tabular}{|c|c|c|c|c|c|c|c|c|c|}
\hline & \multicolumn{3}{|c|}{ Step 1} & \multicolumn{3}{|c|}{ Step 2} & \multicolumn{3}{|c|}{ Step 3} \\
\hline & $\beta$ & $t$ & $p$ & $\beta$ & $t$ & $p$ & $\beta$ & $t$ & $p$ \\
\hline Constant & & 9.05 & $<.001$ & & 9.95 & $<.001$ & & 9.76 & $<.001$ \\
\hline $\operatorname{Sex}(1=\operatorname{men})$ & .03 & 1.09 & .280 & .03 & 1.08 & .280 & .03 & 0.95 & .340 \\
\hline Age & .21 & 6.78 & $<.001$ & .18 & 6.01 & $<.001$ & .18 & 5.83 & $<.001$ \\
\hline Extraversion & .25 & 7.13 & $<.001$ & .22 & 6.61 & $<.001$ & .23 & 6.62 & $<.001$ \\
\hline Agreeableness & .08 & 2.24 & .026 & .08 & 2.49 & .013 & .08 & 2.47 & .014 \\
\hline Neuroticism & -.38 & -11.9 & $<.001$ & -.32 & -9.68 & $<.001$ & -.32 & -9.66 & $<.001$ \\
\hline Consciousness & .23 & 7.29 & $<.001$ & .22 & 7.12 & $<.001$ & .22 & 7.11 & $<.001$ \\
\hline Openness & .07 & 2.19 & .029 & .05 & 1.71 & .087 & .05 & 1.69 & .091 \\
\hline SC Abilities & & & & -.24 & -6.57 & $<.001$ & -.24 & -6.54 & $<.001$ \\
\hline SC Opinions & & & & .08 & 2.12 & .034 & .08 & 2.18 & .030 \\
\hline Intensity of Instagram Use & & & & & & & -.02 & -0.52 & .600 \\
\hline Adjusted $\mathrm{R}^{2}$ & & .47 & & & .51 & & & .51 & \\
\hline$F$ & & $81.2^{* * *}$ & & & $72.7^{* * *}$ & & & $65.4^{* * *}$ & \\
\hline
\end{tabular}

Note. SC Abilities $=$ Social Comparison - ability factor; SC Opinions $=$ Social Comparison - opinion factor. $N=625$.

$* * * p<.001$ 
the beta values of the paths between the variables and the total suppression effect. It is noteworthy that the model with the abilities factor explained $20 \%$ of the self-esteem variance, while the model with the opinions factor explained $7 \%$ of the variance.

\section{Discussion}

The main purpose of this research was to contribute to the knowledge of the predictive power of the intensity of Instagram use, social comparison and personality on Instagram users' self-esteem. The variables, this time investigated together, had already been studied individually and pointed out in the literature as related to self-esteem. In this study, it was found that personality factors - extraversion, agreeableness, neuroticism and conscientiousness - when combined with social comparison in its two dimensions and with the age variable, explain $51 \%$ of the individuals' self-esteem. The intensity of Instagram use, within this regression model, did not contribute to explain the participants' self-esteem, corroborating the results found by Stapleton et al. (2017). Thus, it is possible to suggest that the use of Instagram, by itself, has no direct impact on selfesteem and vice versa.

The difference of averages in the levels of intensity of Instagram use showed that women use it more intensely and, therefore, are more exposed to the activity of comparing themselves with other users. The

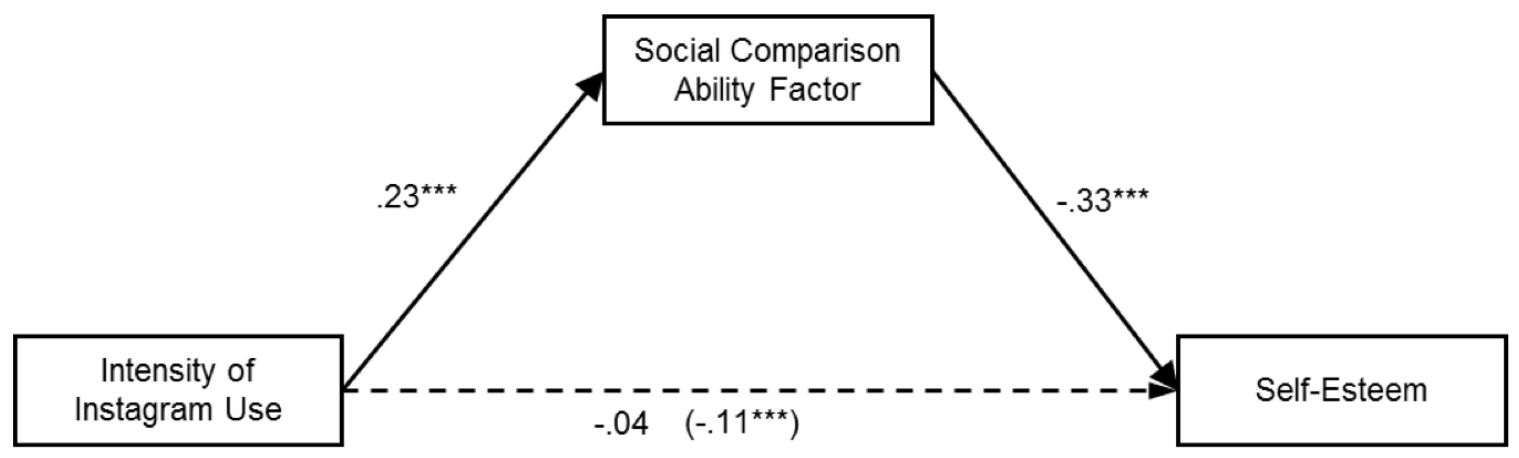

$* * * p<.001$

Figure 1. Relationship between intensity of Instagram use and self-esteem mediated by social comparison - ability factor (supression effect). The values represent the standardized regression coefficients (betas), the value in parenthesis represents the total effect. $R^{2}=0.20$.

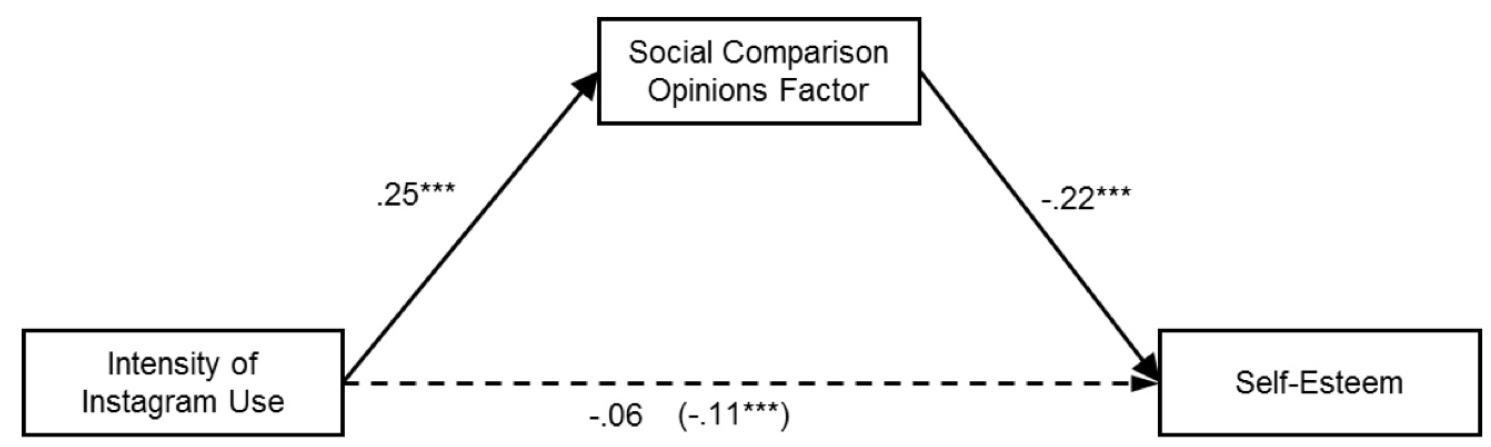

$* * * p<.001$

Figure 2. Relationship between intensity of Instagram use and self-esteem mediated by social comparison - opinion factor (suppression effect). The values represent the standardized regression coefficients (betas), the value in parenthesis represents the total effect. $R^{2}=0.07$. 
correlation coefficients showed that the greater the intensity of use, the higher the levels of social comparison, both in terms of abilities and opinions. Moreover, and only for women, the greater the intensity of Instagram use, the higher the levels of social comparison and the lower the levels of self-esteem. This result is in line with that found by Stapleton et al. (2017), Vogel et al. (2014) and Wang et al. (2017). The information offered by the users themselves in their profiles - even though perhaps not reliable - works as a source of comparison and self-assessment for those who observe those data on the social network. The tendency to favor desirable aspects of oneself and to offer this content publicly to others can be reflected in comparisons that are related to lower levels of self-esteem, characterized by feelings of insecurity and incompetence. Social comparison, previously restricted to the face-to-face universe, gained space in virtual environments where users have the possibility to expose a partial, and sometimes biased, fragment of their lives.

Regarding personality factors, the intensity of Instagram use showed a positive correlation, for both men and women, with neuroticism, supporting previous research (e.g., Zúñiga et al., 2017). Thus, the more emotionally unstable the user is, the more intense his use of Instagram. The constant flow of images made available on Instagram can act as a positive environment where this type of user can escape the troubled social relationships of real life. In addition, the social network allows individuals with high levels of neuroticism to hide their characteristics deemed undesirable and to show in their profiles only what they think it is positive. The insecurity associated with high levels of neuroticism in these individuals can contribute to their losing track of time while reading other people's comments on their photos and/or videos in order to know what others think and say about them (Choi, Sung, Lee, \& Choi, 2017; Ershad \& Aghajani, 2017).

In the same direction as previous research results, self-esteem showed a moderate negative correlation with the neuroticism factor (e.g., Frost \& Natividade, 2017; Hong et al., 2014) and a moderate positive correlation with extraversion (e.g., Hong et al., 2014; Robins et al., 2001). Individuals with higher levels of self-esteem and, therefore, enjoying more self-confidence, tend to demonstrate a higher level of extraversion, being more active and sociable.

If all study variables are taken into account, solely the personality factors - extraversion, agreeableness, neuroticism and conscientiousness - the social comparison (abilities and opinions dimensions) and the age contributed to explain $51 \%$ of the predicted variable, self-esteem. The intensity of Instagram use did not present, within this model, the strength to explain the individuals' self-assessments. However, considering the results of other studies in the literature, social comparison (abilities and opinions factors) was tested as a mediator (suppressor) of the relationship between selfesteem and the intensity of Instagram use. In line with what was found by Stapleton et al. (2017) and Vogel et al. (2014), the relationship between self-esteem and the intensity of Instagram use became significant when social comparison (abilities and opinions factors) was included, highlighting its suppressive role. When mediated by social comparison, the greater the intensity of Instagram use, the lower the self-esteem. Thus, it is possible to infer that the use of Instagram alone, when there is no comparison with other users, does not necessarily relate to the levels of self-esteem.

Those who use online social networks to assess their abilities and opinions by means of comparison are more susceptible to low levels of self-esteem. For example, when someone likes to paint pictures as a hobby and compares his/her productions with those of other people considered superior available on Instagram, he/she increases his/her chances of comparison and, consequently, of evaluating himself/herself as inferior. This can make him/her experience the feeling of incompetence because he/she may believe that he/ she does not have the same ability to make a painting. The contact of the user with different profiles on the online social network, which, intentionally or not, contribute to his/her judging the adequacy of his/her own abilities, can inflict damages on self-assessment, even if what is displayed does not correspond to reality.

This research aimed to contribute to a field of knowledge, still little explored in the Brazilian context, regarding the impact of the intensity of Instagram use, social comparison and personality on the self-esteem of users of that online social network. Despite the advances in understanding the subject, some limitations of the study deserve to be highlighted. The non-representative sample of the population makes it impossible to generalize the results found, confining them to the characteristics of the examined sampling. Another limitation is based on the need for caution when comparing the results of this research with those found by other inquiries, since most of the studies that served as a basis for this investigation were carried out with Facebook or other online social networks, which present 
different specificities of use and a different impact on users' lives. As a further limitation, it should be considered that the types of Instagram use, active or passive, were not investigated, and this aspect might have different effects on the activity of social comparison and self-assessment.

Finally, it should be added that Instagram is an online social network with a specific focus on images. This characteristic emphasizes the importance of studying in the future the body image dimension of self-concept and its relationship with other variables and self-esteem. Furthermore, in view of the value attributed by teenagers to body aesthetics, the study of these variables with a sample of teenagers may help prevent damages to individuals that are still undergoing the early stages of their upbringing.

\section{References}

Andreassen, C. S., Pallesen, S., \& Griffiths, M. D. (2017). The relationship between addictive use of social media, narcissism, and self-esteem: Findings from a large national survey. Addictive Behaviors, 64, 287293. doi: 10.1016/j.addbeh.2016.03.006

Bastos, R. V. S., Marot, A. T., \& Natividade, J. C. (2019). Adaptação da Iowa-Netherlands Comparison Orientation Measure (INCOM) para o contexto brasileiro.[Adaption of Iowa-Netherlands Comparison Orientation Measure (INCOM) to the Brazilian context]. Poster presented at $9^{\circ}$ Congresso Brasileiro de Avaliação Psicológica, Salvador, BA.

Choi, T. R., Sung, Y., Lee, J. A., \& Choi, S. M. (2017). Get behind my selfies: The Big Five traits and social networking behaviors through selfies. Personality and Individual Differences, 109, 98-101. doi: 10.1016/j.paid.2016.12.057

Chung, J. M., Robins, R. W., Trzesniewski, K. H., Noftle, E. E., Roberts, B. W., \& Widaman, K. F. (2014). Continuity and change in self-esteem during emerging adulthood. Journal of Personality and Social Psychology, 106, 469-483. doi: 10.1037/a0035135

Clement, J. (2019a, Dezembro 3). Number of monthly active Instagramusersfrom January 2013 toJune 2018. Retrieved from https://www.statista.com/statistics/253577/ number-of-monthly-active-instagram-users/

Clement,J.(2019b, Novembro20). Leadingcountriesbasedon number of Instagram users as of October 2019. Retrieved from https://www.statista.com/statistics/578364/ countries-with-most-instagram-users/

Donnellan, M. B., Larsen-Rife, D., \& Conger, R. D. (2005). Personality, family history, and competence in early adult romantic relationships. Journal of Personality and Social Psychology, 88, 562576. doi:10.1037/0022-3514.88.3.562

Ellison, N., Heino, R., \& Gibbs, J. (2006). Managing impressions online: Self-presentation processes in the online dating environment. Journal of Computer-Mediated Communication, 11, 415-441. doi:10.1111/j.1083-6101.2006.00020.x

Ellison, N. B., Steinfield, C., \& Lampe, C. (2007). The benefits of Facebook "friends:" Social capital and college students' use of online social network sites. Journal of Computer-Mediated Communication, 12, 1143-1168. doi: 10.1111/j.1083-6101.2007.00367.x

Ershad, Z. S., \& Aghajani, T. (2017). Prediction of Instagram social network addiction based on the personality, alexithymia and attachment Styles. Sociological Studies of Youth, 8, 21-34.

Festinger, L. (1954). A theory of social comparison processes. Human Relations, 7, 117-140. doi:10.1177/001872675400700202

Frost, A. S., \& Natividade, J. C. (2017). Self-esteem predicting subjective well-being beyond big five factors of personality. Poster presented at 5th World Congress of the International Positive Psychology Association, Montreal, Canada. doi: 10.13140/ RG.2.2.17903.38564

Gibbons, F. X., \& Buunk, B. P. (1999). Individual differences in social comparison: development of a scale of social comparison orientation. Journal of Personality and Social Psychology, 76, 129-142. doi:10.1037/0022-3514.76.1.129

Hayes, A. F. (2018). An introduction to mediation, moderation, and conditional process analysis: A regression-based approach $\left(2^{a} \mathrm{Ed}\right.$.). New York, NY: Guilford Press.

Heatherton, T. F., \& Wyland, C. L. (2003). Assessing self-esteem. In S. J. Lopez \& C. R. Snyder (Eds.), Positive psychological assessment: A handbook of models and measures (pp. 219-233). Washington: American Psychological Association.

Hong, F. Y., Huang, D. H., Lin, H. Y., \& Chiu, S. L. (2014). Analysis of the psychological traits, Facebook usage, and Facebook addiction model of 
Taiwanese university students. Telematics and Informatics, 3, 597-606. doi: 10.1016/j.tele.2014.01.001

Hu, Y., Manikonda, L., \& Kambhampati, S. (2014). What we Instagram: A first analysis of Instagram photo content and user types. Proceedings of the Eighth International AAAI Conference on Weblogs and Social Media, 595-598.

Hutz, C. S., \& Zanon, C. (2011). Revisão da adaptação, validação e normatização da escala de autoestima de Rosenberg. [Revision of the adaptation, validation, and normatization of the Roserberg self-esteem scale]. Avaliação Psicológica, 10(1), 41-49.

Hutz, C. S., Zanon, C., \& Vazquez, A. C. S. (2014). Escala de autoestima de Rosenberg [Rosenberg's self-esteem scale]. In C. S. Hutz (Org), Avaliação em psicologia positiva (pp. 85-94). Porto Alegre: Artmed.

Jan, M., Soomro, S. A., \& Nawaz, A. (2017). Impact of social media on self-esteem. European Scientific Journal, 13, 329-341. doi: 10.19044/esj.2017. v13n23p329

Kayiş, A. R., Satici, S. A., Yilmaz, M. F., Şimşek, D., Ceyhan, E., \& Bakioğlu, F. (2016). Big five-personality trait and internet addiction: A meta-analytic review. Computers in Human Behavior, 63, 35-40. doi: 10.1016/j.chb.2016.05.012

Kemp, S. (2019, Janeiro 31). Digital 2019: Global digital overview. Retrieved from https://datareportal.com/ reports/digital-2019-global-digital-overview

Kircaburun, K., \& Griffiths, M. D. (2018). Instagram addiction and the Big Five of personality: The mediating role of self-liking. Journal of Behavioral Addictions, 7, 158-170. doi: 10.1556/2006.7.2018.15

Ko, C. H., Yen, J. Y., Chen, C. C., Chen, S. H., Wu, K., \& Yen, C. F. (2006). Tridimensional personality of adolescents with internet addiction and substance use experience. The Canadian Journal of Psychiatry, 51, 887-894. doi: 10.1177/070674370605101404

Komarraju, M., Karau, S. J., \& Schmeck, R. R. (2009). Role of the Big Five personality traits in predicting college students' academic motivation and achievement. Learning and Individual Differences, 19, 47-52. doi: 10.1016/j.lindif.2008.07.001

Kross, E., Verduyn, P., Demiralp, E., Park, J., Lee, D. S., Lin, N., Shablack, H., Jonides, J., \& Ybarra, O. (2013). Facebook use predicts declines in subjective well-being in young adults. PloS One, 8(8). doi: 10.1371/journal.pone.0069841

Kuss, D. J., \& Griffiths, M. D. (2011). Online social networking and addiction - A review of the psychological literature. International Journal of Environmental Research and Public Health, 8, 3528-3552. doi:10.3390/ijerph8093528

Kwan, V. S., Bond, M. H., \& Singelis, T. M. (1997). Pancultural explanations for life satisfaction: Adding relationship harmony to self-esteem. Journal of Personality and Social Psychology, 73, 1038-51. doi:10.1037/0022-3514.73.5.1038

Leary, M. R., Tambor, E. S., Terdal, S. K., \& Downs, D. L. (1995). Self-esteem as an interpersonal monitor: The sociometer hypothesis. Journal of Personality and Social Psychology, 68, 518-530. doi: 10.1037/0022-3514.68.3.518

Lee, S. Y. (2014). How do people compare themselves with others on social network sites?: The case of Facebook. Computers in Human Behavior, 32, 253260. doi:10.1016/j.chb.2013.12.009

Lee-Won, R. J., Shim, M., Joo, Y. K., \& Park, S. G. (2014). Who puts the best "face" forward on Facebook?: Positive self-presentation in online social networking and the role of self-consciousness, actual-to-total Friends ratio, and culture. Computers in Human Behavior, 39, 413-423. doi: 10.1016/j. chb.2014.08.007

Lin, R., \& Utz, S. (2015). The emotional responses of browsing Facebook: Happiness, envy, and the role of tie strength. Computers in Human Behavior, 52, 29 38. doi:10.1016/j.chb.2015.04.064

Lins, S. L. B., Campos, M., Leite, A. C., Carvalho, C. L., Cardoso, S., \& Natividade, J. C. (2016). Evidências de validade da Escala de Orientação para a Comparação Social (INCOM) para o contexto de adolescentes portugueses. [Validity evidence for Scale for Social Comparison Orientation (INCOM) in the Portuguese adolescents' context]. Psicologia, 30(1), 1-14. doi: 10.17575/rpsicol.v30i1.1034

Lup, K., Trub, L., \& Rosenthal, L. (2015). Instagram \#instasad?: Exploring associations among Instagram use, depressive symptoms, negative social comparison, and strangers followed. Cyberpsychol ogy, Behavior, and Social Networking, 18, 247-252. doi: 10.1089/cyber.2014.0560 
Malik, S., \& Khan, M. (2015). Impact of Facebook addiction on narcissistic behavior and self-esteem among students. Journal of Pakistan Medical Association, 65, 260-263.

Meier, A., \& Schäfer, S. (2018). The positive side of social comparison on social network sites: How envy can drive inspiration on Instagram. Cyberpsychology, Behavior, and Social Networking, 21, 411-417. doi: 10.1089/cyber.2017.0708

Natividade, J. C., \& Hutz, C. S. (2015). Escala reduzida de descritores dos cinco grandes fatores de personalidade: Prós e contras. [Short scale of the big five personality factors descriptors: pros and cons] Psico(PUCRS), 46, 79-89. doi: 10.15448/1980-8623.2015.1.16901

Natividade, J. C., \& Hutz, C. S. (2016). Personal characteristics associated with sexuality can be classified into seven dimensions in Brazil. Personality and Individual Differences, 97, 88-97. doi: 10.1016/j. paid.2016.03.030

Natividade, J. C., Aguirre, A. R., Bizarro, L., \& Hutz, C. S. (2012). Fatores de personalidade como preditores do consumo de álcool por estudantes universitários. [Personality factors as predictors of alcohol consume by university students]. Cadernos de Saúde Pública, 28(6), 1091-1100. doi: 10.1590/ S0102-311X2012000600008

Natividade, J. C., Carvalho, N. M., Londero-Santos, A., Carvalho, T. F., Santos, L. S., \& Fagundes, L. S. (2019). Gratidão no contexto brasileiro: mensuração e relações com personalidade e bem-estar. [Gratitude in the Brazilian context: Measurement and relationship with personality and well-being]. Avaliação Psicológica, 18(4), 400-410. doi: 10.15689/ ap.2019.1804.18712.08

Neal, A., Yeo, G., Koy, A., \& Xiao, T. (2012). Predicting the form and direction of work role performance from the Big5 model of personality traits. Journal of Organizational Behavior, 33, 175-192. doi: 10.1002/ job.742

Pullmann, H., \& Allik, J. (2000). The Rosenberg Self-Esteem Scale: Its dimensionality, stability and personality correlates in Estonian. Personality and Individual Differences, 28, 701-715. doi: 10.1016/ S0191-8869(99)00132-4
R Core Team (2019). R: A language and environment for statistical computing. $R$ Foundation for Statistical Computing, Vienna, Austria.

Reinecke, L., \& Trepte, S. (2014). Authenticity and well-being on social network sites: A two-wave longitudinal study on the effects of online authenticity and the positivity bias in SNS communication. Computers in Human Behavior, 30, 95-102. doi: 10.1016/j.chb.2013.07.030

Robins, R. W., Hendin, H. M., \& Trzesniewski, K. H. (2001). Measuring global self-esteem: Construct validation of a single-item measure and the Rosenberg Self-Esteem Scale. Personality and Social Psychology Bulletin, 27, 151-161. doi: 10.1177/0146167201272002

Robins, R. W., Tracy, J. L., Trzesniewski, K., Potter, J., \& Gosling, S. D. (2001). Personality correlates of self-esteem. Journal of Research in Personality, 35, 463-482. doi: 10.1006/jrpe.2001.2324

Rosenberg, M. (1965). The Measurement of SelfEsteem. In M. Rosenberg (Ed.), Society and the Adolescent Self-Image (pp. 16-36). Princeton University Press.

Rosenberg, M., Schooler, C., Schoenbach, C., \& Rosenberg, F. (1995). Global self-esteem and specific self-esteem: Different concepts, different outcomes. American Sociological Review, 60(1), 141156. doi: $10.2307 / 2096350$

Rosseel, Y. (2012). lavaan: An R package for structural equation modeling. Journal of Statistical Software, 48(2), 1-36.

Schmuck, D., Karsay, K., Matthes, J., \& Stevic, A. (2019). "Looking up and feeling down". The influence of mobile social networking site use on upward social comparison, self-esteem, and well-being of adult smartphone users. Telematics and Informatics, 42. doi: 10.1016/j.tele.2019.101240

Stapleton, P., Luiz, G., \& Chatwin, H. (2017). Generation validation: The role of social comparison in use of Instagram among emerging adults. Cyberpsychology, Behavior, and Social Networking, 20, 142-149. doi: $10.1089 /$ cyber.2016.0444

Trifiro, B. (2018). Instagram use and it's effect on well-being and self-esteem (Master's thesis). Retrieved from https://digitalcommons.bryant.edu/macomm/4/ 
Trzesniewski, K. H., Donnellan, M. B., \& Robins, R. W. (2003). Stability of self-esteem across the life span. Journal of Personality and Social Psychology, 84, 205-220. doi: 10.1037/0022-3514.84.1.205

Verduyn, P., Ybarra, O., Résibois, M., Jonides, J., \& Kross, E. (2017). Do social network sites enhance or undermine subjective well-being? A critical review. Social Issues and Policy Review, 11, 274-302. doi: 10.1111/sipr.12033

Vogel, E. A., Rose, J. P., Roberts, L. R., \& Eckles, K. (2014). Social comparison, social media, and selfesteem. Psychology of Popular Media Culture, 3, 206. doi: $10.1037 / \mathrm{ppm} 0000047$

Vries, D. A., Möller, A. M., Wieringa, M. S., Eigenraam, A. W., \& Hamelink, K. (2017). Social comparison as the thief of joy: Emotional consequences of viewing strangers' Instagram posts. Media Psychology, 21, 222-245. doi: 10.1080/15213269.2016.1267647

Wachelke, J. F. R, Natividade, J. C., Andrade, A. L., Wolter, R., \& Camargo, B. V. (2014). Caracterização e avaliação de um procedimento de coleta de dados online (CORP). [Characterization and assessment of an online data collection procedure (CORP)]. Avaliação Psicológica, 13(1), 143-146.

Walther, J. B. (2007). Selective self-presentation in computer-mediated communication: Hyperpersonal dimensions of technology, language, and cognition. Computers in Human Behavior, 23, 2538-2557. doi: 10.1016/j.chb.2006.05.002

Wang, S. S. (2013). "I share, therefore I am": Personality traits, life satisfaction, and Facebook check-ins. Cyberpsychology, Behavior, and Social Networking, 16, 870-877. doi: 10.1089/cyber.2012.0395
Wang, J. L., Wang, H. Z., Gaskin, J., \& Hawk, S. (2017). The mediating roles of upward social comparison and self-esteem and the moderating role of social comparison orientation in the association between social networking site usage and subjective wellbeing. Frontiers in Psychology, 8, 1-9. doi: 10.3389/ fpsyg.2017.00771

Wood, J. V. (1989). Theory and research concerning social comparisons of personal attributes. Psychological Bulletin, 106, 231-248. doi: 10.1037/0033-2909.106.2.231

Woyciekoski, C., Natividade, J. C., \& Hutz, C. S. (2014). As contribuições da personalidade e dos eventos de vida para o bem-estar subjetivo. [Contributions of personality and life events to the subjective wellbeing]. Psicologia: Teoria e Pesquisa, 30(4), 401-409.

Yang, C. C. (2016). Instagram use, loneliness, and social comparison orientation: interact and browse on social media, but don't compare. Cyberpsychology, Behavior, and Social Networking, 19, 703-708. doi: 10.1089/cyber.2016.0201

Zúñiga, H.G., Diehl, T., Huber, B., \& Liu, J. (2017). Personality traits and social media use in 20 countries: How personality relates to frequency of social media use, social media news use, and social media use for social interaction. Cyberpsychology, Behavior, and Social Networking, 20, 540-552. doi: 10.1089/ cyber.2017.0295

Recebido em: 04/12/2018 Reformulado em: 03/01/2020 Aprovado em: 21/01/2020 
About the authors:

Luiza Seabra Fagundes - Master in Psychology from the Graduate Program in Psychology of the Pontifícia Universidade Católica do Rio de Janeiro. Graduated in Psychology at the Pontifícia Universidade Católica do Rio de Janeiro. Clinical psychologist.

ORCID: https://orcid.org/0000-0002-3835-3966

E-mail: luiza_fagundes@hotmai.com

Tiago Azevedo Marot - Master's student at the Graduate Program in Psychology of the Pontifícia Universidade Católica do Rio de Janeiro.

ORCID: https://orcid.org/0000-0002-4491-4993

E-mail: marottiago@gmail.com

Jean Carlos Natividade - Professor at the Graduate Program in Psychology of the Pontifícia Universidade Católica do Rio de Janeiro. Coordinator of the Social Psychology Research Laboratory at PUC-Rio.

ORCID: https://orcid.org/0000-0002-3264-9352

E-mail: jeannatividade@gmail.com

\section{Contact:}

Jean C. Natividade

Social Psychology Research Laboratory (L2PS)

PUC-Rio. Department of Psychology

Rua Marquês de São Vicente, 225, Gávea

Rio de Janeiro, RJ-Brazil

CEP: 22451-900

http://www.L2PS.org 